\title{
Verification of the Geometrical Representation of Buildings in Cadastre Using UAV Photogrammetry
}

Abstract: The aim of this study was to determine the potential benefits of using UAV-based data to verify the accuracy of the geometry of the outlines of buildings registered in a cadastral database, and to investigate the potential use of data from UAV platforms in measuring the buildings.

The authors examined whether the acquisition of data from UAVs can replace field measurements or only support them. The advantages and disadvantages of such data acquisition methods, compared with more well-established measurement methods, were identified.

Keywords: UAV, cadastre, buildings, outlines of buildings, photogrammetry

Received: 31 July 2021; accepted: 16 September 2021

(C) 2021 Authors. This is an open access publication, which can be used, distributed and reproduced in any medium according to the Creative Commons CC-BY 4.0 License.

1 Warsaw University of Technology, Faculty of Geodesy and Cartography, Department of Cadastre and Land Management, Warsaw, Poland, email: marcin.karabin@pw.edu.pl, ORCID ID: https://orcid.org/0000-0003-0812-3219

2 Warsaw University of Technology, Faculty of Geodesy and Cartography, Department of Photogrammetry, Remote Sensing and Spatial Information Systems, Warsaw, Poland, email: krzysztof.bakula@pw.edu.pl, ORCID ID: https://orcid.org/0000-0001-7137-1667

3 Warsaw University of Technology, Faculty of Geodesy and Cartography, Department of Cadastre and Land Management, Warsaw, Poland, email: robert.luczynski@pw.edu.pl,

ORCID ID: https://orcid.org/0000-0001-5887-2176 


\section{Introduction}

Nowadays, important elements of any work are its execution time and the necessary financial outlays. Therefore, more efficient tools and technologies are sought in an effort to further improve these elements. Emerging new measurement technologies provide an opportunity to work more effectively. A necessary stage in the introduction of a given measurement method is to examine its suitability for a given purpose. The most important and necessary criterion to meet is to achieve the requisite degree of surveying accuracy. In many countries, including Poland, these degrees of accuracy are strictly defined by legal regulations. In some cases, legal regulations also list the purposes for which a given measurement method can or should not be used. Therefore, the authors reviewed the legal regulations in Poland concerning the field of geodetic measurements and cadastre. Subsequently, experimental work was designed and carried out using UAVs, which are representative of a dynamic, rapidly developing market. The research aimed to investigate the accuracy of obtaining geometric data on buildings in Poland using this method.

The term "cadastral surveying" will in this study refer to measurements of field details which form the content of cadastral maps in accordance with the requirements of the regulation [1], particularly boundary points and marks, land use outlines, soil map delineations, and outlines of buildings [2]. Boundary points and marks should be defined by the State Plane Rectangular Coordinate System (2000), with the root mean square error (RMSE) not higher than $0.30 \mathrm{~m}$ in relation to the points of the first-class geodetic network, based on site measurements in a way that guarantees the mapping of the location and shape of spatial objects and their mutual relationship. It is important to note that a boundary point (which is also the boundary break point) defines the range of ownership of a land parcel which - according to the definition given in the regulation [1] - must meet the criterion of so-called legal homogeneity. The course of the boundaries of cadastral parcels should be considered in the technological and legal space, the coherence of which is represented by the area that is a common part of the technological and legal subspaces. The technological subspace is a set of boundary points, specified by surveys and appropriate documentation, which allows for explicit restoration of the location of boundary points in the field; the $X, Y$ coordinates of such points were determined in accordance with the principles of uniformity of surveying and cartographic works. The uniformity of surveying and cartographic works is understood as a uniform system of measures, a uniform state spatial reference system and a set of uniform technical standards. The legal subspace is a set of administrative and judicial procedures, the result of which is the legal approval of the established location of boundary points and borderlines [2]. The boundary of a land parcel may, therefore, define the scope of the ownership title to a given property. This means that every measurement of a point or boundary mark must be supported by an analysis of documentation describing the legal status of a property, as well as the documentation describing the 
parcel boundaries referred to in the regulation [3]. According to $\S 37$ of the regulation [1], data defining the parcel boundaries is obtained from site measurements or photogrammetric surveys; this is preceded by determining the shape of these boundaries only if reliable documentation defining these boundaries cannot be found in the National Geodetic and Cartographic Resources.

The new cadastral regulation [4], which will apply from August 2021, does not explicitly mention the measurement technologies used in cadastral measurements. The regulation included in paragraph 33 point 4 states only that boundary points are marked on the ground in a way that allows their measurement. The possibility of determining the boundaries on the basis of aerial, satellite or orthophoto map images will therefore depend on first determining the border point on the ground, and then carrying out photogrammetric works.

According to $\S 39$ of the regulation [1], the defining of parcel boundaries (required in the absence of reliable parcel boundary documentation) should be:

1) based on joint recommendations from parcel owners/perpetual usufructuaries or from entities who manage the parcel as autonomous possessors; confirmed by their joint statements made in line with the protocol of determining the parcel boundaries;

2) based on the latest peaceful state of possession, provided that the state of possession is consistent with information contained in the available documentation describing the legal status of the parcel involved;

3) carried out after analysis of the location of boundary signs and traces, and after an analysis of all available documents containing information relevant to the entity, including statements made by the stakeholder entities and witnesses.

The new regulation [4] does not introduce significant changes in this respect, adding only in the first criterion of the joint declaration of the parties that the indicated course does not contradict the information contained in the available documents on the course of the established boundaries. It is important to note that the application of criterion 1) requires a joint statement from the parties concerning the parcel boundaries, and the results of this statement are immediately recorded on the basis of field measurements and documented in a report prepared on site. In such circumstances, the application of photogrammetry seems unreasonable when compared with the benefits of GNSS technology. Only when it comes to criterion 2) may photogrammetric technology be of use in direct field measurements of the particular properties, especially of balks separating farmland, but only under the old regulation [1] and not now.

Taking into account the requirements for determining the location of boundary points (firstly on the basis of the results of geodetic analysis of data kept in the National Geodetic and Cartographic Resources Database, and then - if such data is unavailable - on the basis of field measurements preceded by determining the 
parcel boundaries), and secondly, the precisely defined criteria for determining parcel boundaries, the application of photogrammetric measurements of the location of boundary points seems to be a procedure which supports only the direct field measurements carried out by a surveyor in the presence of the stakeholders and immediately confirmed by the protocol prepared on site.

According to the regulation [5]:

1) boundary points and marks, as well as buildings, are field details of the socalled group I, which require site measurement in reference to the horizontal geodetic reference network or the geodetic control point network, the precision of which measurements must not fall below $0.10 \mathrm{~m}$;

2) the land use outlines are field details of group III, and they require site measurements in relation to the points of the horizontal geodetic reference network or the geodetic control points network with an accuracy of not less than $0.50 \mathrm{~m}$.

Aerial photographs obtained from manned or unmanned aerial vehicles have enormous information potential, while also serving as material for objective evidence. Compared to standard measurement methods, those based on photogrammetric products are not so time-consuming and enable remote recording, enabling the analysis of even hard-to-reach areas [6]. Contrary to the measurement of boundary points, where the appropriate legal procedure requires measurements to be made at a specific time in the presence of stakeholders, no such procedure must be followed when measuring building and land use outlines. The possibility of using photogrammetric technology in the measurement of land use outlines seems to be highly justified, especially when working on extensive agricultural areas. The effectiveness of photogrammetry in measuring building outlines will be verified on the basis of the results of tests carried out using measurements collected by a drone.

There is no doubt that the Unmanned Aerial Vehicle (UAV) is a very useful system that has come to be used to solve a wide range of problems. In parallel with the developing technology, UAVs have begun to be used in recent years through integration with the Global Navigation Satellite System (GNSS) (especially real-time kinematic (RTK) solutions), inertial measurement units (IMU) and high-resolution cameras. Remote sensing has started to be used in commercial and scientific research, such as digital mapping, monitoring of landslides and disasters, as well as monitoring and planning of agricultural land [7]. However, recently UAV solutions have been able to achieve centimetre-level accuracy, comparable to direct surveying methods, which is the reason for using drones in cadastral issues related to parcel boundaries [8-18]. All UAV regulations have the common goal of minimizing the risks to other airspace users and to both people and property on the ground. Furthermore, besides the clear presence of legal frameworks, market forces such as industry design standards and reliable information about UAVs as public goods are expected to shape future developments [19]. 
Referring to buildings, another important source of cadastral information, studies of the accuracy of some building measurements have been carried out by Vacca et al. [20], in which measurements such as widths, heights, areas, and volumes have been taken from 3D models obtained from processing images acquired from the UAV system. The RMS error in the distances between the walls from the UAV are in the order of $6 \mathrm{~cm}$ for the flight (processed with Agisoft Photoscan) and $7 \mathrm{~cm}$ for the nadir flight (processed with Pix4D). The study of Kędzierski [21] shows that UAV imaging allows for photogrammetric block adjustment and orthomosaics with a mean spatial accuracy of $0.11 \mathrm{~m}$ - to be made. As can be determined from the study [22], the accuracy of building measurements taken at a photogrammetric station by stereo-digitalization (stereo measurement) of a model compiled from photographs of resolution GSD $=0.10 \mathrm{~m}$ ranges from 0.10 to $0.15 \mathrm{~m}$ (RMS error). This high degree of accuracy is a product of several factors, being additionally increased by the ability to identify and measure the shadowed corner of the building.

This means that UAV photogrammetry offering the aforementioned accuracy can be widely used to measure land use boundaries, but it is not sufficiently precise in measuring boundary points and outlines of buildings. The results of studies assessing the effectiveness of unmanned aerial vehicles in measuring land use boundaries are given in [23], where it has also been demonstrated that measurements to establish land and building records in rural areas were often made without a network, that is, they were measured from a balk break point or from a crossroads. Roads and balks often tended to change their lines, causing problems in determining the actual property boundaries. For example, there were a few instances of two different surveyor crews working simultaneously on neighboring properties. The unfortunate lack of coordination and information sharing led to completely different sets of basic trigonometry data for the same boundary points. For this reason, the use of data from the Land and Building Register in ongoing works is highly difficult and often requires the re-establishment of the property boundaries. The study [24] consisted of making photogrammetric flights, processing measurements (including bundle adjustment in various configurations for defining projection centers of photos), direct georeferencing (GNSS + RTK), and typical aerial triangulation supported by initial exterior orientation. The results were compared with the plot boundaries. The authors [24] believe that this experiment should be repeated because they suspect that RTK adjustments were not included in the mean projections exported to the text file.

The study [9] examines recent efforts to make the process of cadastral mapping more reproducible, transparent, automated, scalable and cost-effective. This is investigated by proposing the application of UAV orthoimages in conjunction with automated image analysis. The approach does not require prior knowledge and automatically detects objects from UAV orthoimages that indicate visible cadastral boundaries. More specifically, this study explores the transferability of boundary detection to UAV images and its applicability to automated delineation of objects demarcating visible parcel boundaries. 
As the study [10] shows, the accuracy achieved with the orthophoto map and the digital surface model (DSM) satisfied the applicable Polish legal requirements, with the maximum deviations for individual check points not exceeding $0.1 \mathrm{~m}$.

In the following experiment, the authors examined whether the acquisition of data from UAVs can replace field measurements or only support them. Datasets collected using low-altitude photogrammetry are compared to GNSS RTK measurements and to reference evidence datasets.

\section{Experiment and Results}

This section presents a measurement platform and a testing area; it also describes the experiment carried out to determine the functionality of UAV imagery in checking the geometrical data of buildings for cadastral needs, and to answer the question of whether it offers any alternative to more established measurement methods, including those employing GNSS technology. The experiment was conducted by a research team from Warsaw University of Technology, supported by the MSP photogrammetry company in Podkampinos. Podkampinos is a cadastral district located in the Kampinos Municipality (about $40 \mathrm{~km}$ north-west of Warsaw); it is a rural area of about $3 \mathrm{~km}^{2}$, with small agricultural parcels and village buildings.

\subsection{Methodology and Datasets}

The study area had its cadastral records modernized (by way of an updating process) in order to obtain geometric data of buildings. The modernization process took place in September 2014 and utilized the tacheometric method to measure buildings from measurement control points established using GNSS technology. Data from UAV platforms was obtained in autumn 2015, and in February 2016 a control measurement of building corners was conducted with the offset method using GNSS-RTN technology. The short lag time between the first measurement and the control measurement in the course of the experiment guaranteed a high level of probability that the buildings on which the measurements were made were not modified in the meantime (no improvements, Styrofoam thermal insulation, etc.).

The fixed-wing platforms were designed to collect RGB images. The images were taken with a Sony A7R camera equipped with an FE 2/28 lens and a CMOS sensor (with dimensions of $35.8 \mathrm{~mm} \times 23.9 \mathrm{~mm}$ and a resolution of $7380 \times 4912$ pixels (36 Mpx)). The images had a GSD of $0.03 \mathrm{~m}$, with an end overlap of $p=80 \%$ and a side overlap of $q=60 \%$. A total of 1660 images were collected and processed in Pix $4 \mathrm{~d}$ software in bundle adjustment with self-calibration of the camera using 21 control and check points. The planned $80 / 60$ overlap guaranteed that each potentially measured point could be observed in at least 6 images. The results that were obtained in this photogrammetric processing are described in [8]. The RMS for control points was calculated to be $0.018 \mathrm{~m}, 0.018 \mathrm{~m}$ and $0.013 \mathrm{~m}$ for $X, Y$ and $Z$ respectively, and during 
verification of the check points, the RMS errors were $0.043 \mathrm{~m}, 0.047 \mathrm{~m}$ and $0.074 \mathrm{~m}$ respectively, constituting a slightly lower degree of accuracy.

Data obtained from the UAVs allowed several photogrammetric products to be created, such as an orthophoto map, a digital surface model, a slope map, and a 3D model, all of which use advanced visualization to present the results. All of these products could be used to facilitate surveying.

The authors [8] conducted a general analysis of the data obtained from the UAV platform, that is to say, the geometric data of buildings collected from a 3D model within multiple space intersections ( $X, Y$ coordinates), are comparable to those obtained in direct control measurement in the field. The authors of this paper carried out a control field measurement of building corners with the offset method using GNSS-RTN technology to prove this statement and review individual cases of building. The control measurement was made with a Kolida K9-T receiver with a manual Leica DISTO D8 rangefinder in reference to the ASG EUPOS network. The control measurement covered buildings located in various parts of the study area, as well as on the periphery of the photogrammetric works.

In Figure 1, the distribution of the control measurement is presented. Several of them were presented in this section as cases for discussion and analysis to ascertain the usefulness of UAVs in the measurement of buildings.

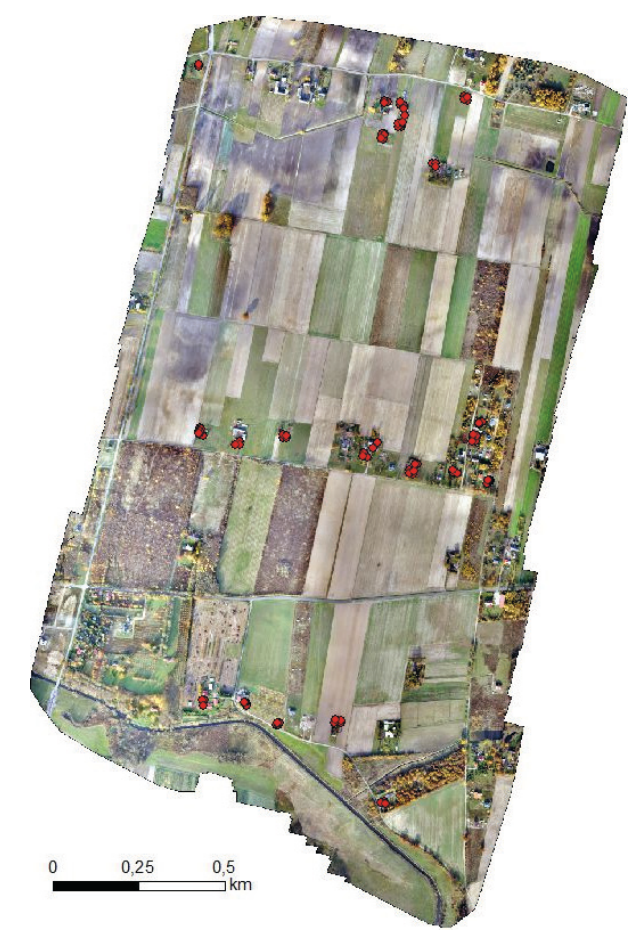

Fig. 1. Distribution of building corners measured with direct surveying measurements 


\section{Case 1 - building on parcel 92}

As can be seen in Table 1, the differences between coordinates do not exceed $30 \mathrm{~cm}$, excluding point 31E. We can, therefore, assume that the measured building was in an unchanged state (in terms of its physical geometry in the field) during the process of cadastral database modernization (the updating process), using UAV and during GNSS control measurements (visualization of such data can be seen in Figure 2). The analysis of field drawings (Fig. 3) shows that some elements of the building have been changed (some walls have been rebuilt with additional thermal insulation). So, for this building, we can only compare the coordinates of some of the building's corners, not all of them. The authors believe that only this type of assessment of the building condition at the time of source measurement and control measurement permits comparison of these data with data obtained from a UAV platform. Otherwise, the analysis would show discrepancies caused by physical changes occurring to objects between the source measurement time and the time of control measurement. For unchanged elements, this case shows that it is possible to use UAV measurements to obtain geometric data for buildings, as they give results comparable to those of GNSS and tachymetry.

Table 1. Comparison of coordinates obtained from cadastral database and from author's GNSS control measurement

\begin{tabular}{||c|c|c|c|c|c|c|c|c||}
\hline \multicolumn{3}{|c|}{ Cadastral database } & \multicolumn{3}{|c|}{ GNSS measurement } & & & \\
\hline Point id & $X$ & $Y$ & Point id & $X$ & $Y$ & $\mathrm{~d} X[\mathrm{~m}]$ & $\mathrm{d} Y[\mathrm{~m}]$ & $\mathrm{d} p[\mathrm{~m}]$ \\
\hline \hline 22E & 5790809.83 & 7462782.13 & BD11 & 5790810.13 & 7462782.08 & -0.30 & 0.05 & 0.30 \\
\hline 23E & 5790807.37 & 7462791.80 & BD20 & 5790807.52 & 7462792.03 & -0.15 & -0.23 & 0.27 \\
\hline $24 \mathrm{E}$ & 5790803.14 & 7462790.70 & BD19 & 5790803.19 & 7462790.84 & -0.05 & -0.14 & 0.15 \\
\hline $25 \mathrm{E}$ & 5790802.84 & 7462791.88 & BD18 & 5790802.88 & 7462791.99 & -0.04 & -0.11 & 0.12 \\
\hline 26E & 5790797.95 & 7462790.59 & BD17 & 5790797.85 & 7462790.62 & 0.10 & -0.03 & 0.10 \\
\hline 27E & 5790798.24 & 7462789.45 & BD16 & 5790798.15 & 7462789.43 & 0.09 & 0.02 & 0.09 \\
\hline 28E & 5790793.87 & 7462788.32 & BD15 & 5790793.78 & 7462788.28 & 0.09 & 0.04 & 0.10 \\
\hline 29E & 5790794.86 & 7462784.40 & BD14 & 5790794.76 & 7462784.26 & 0.10 & 0.14 & 0.17 \\
\hline 30E & 5790791.21 & 7462783.46 & BD13 & 5790790.91 & 7462783.33 & 0.30 & 0.13 & 0.33 \\
\hline 31E & 5790792.68 & 7462777.72 & BD12 & 5790792.52 & 7462777.34 & 0.16 & 0.38 & 0.41 \\
\hline
\end{tabular}


a)

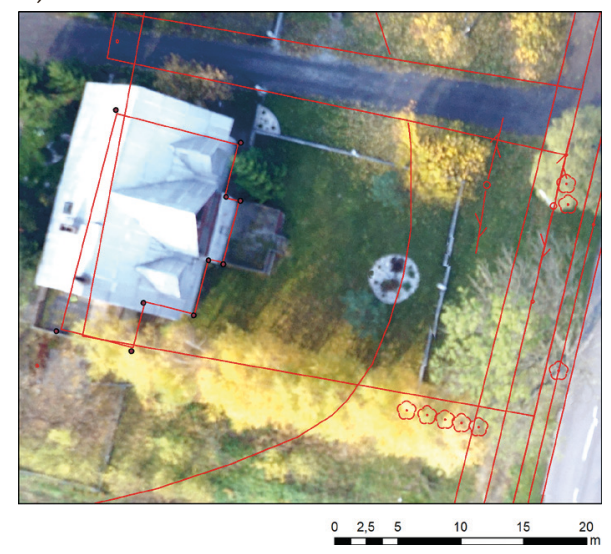

b)

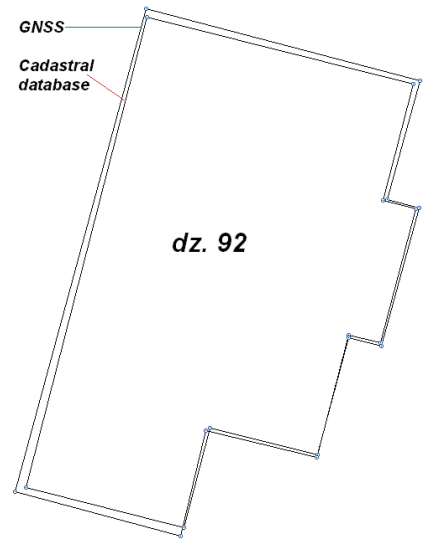

Fig. 2. UAV ortomosaic overlaid with cadastral map presenting parcel no. 92 (a) and comparison of building outlines acquired from cadastral database and UAV-based data (b)

a)

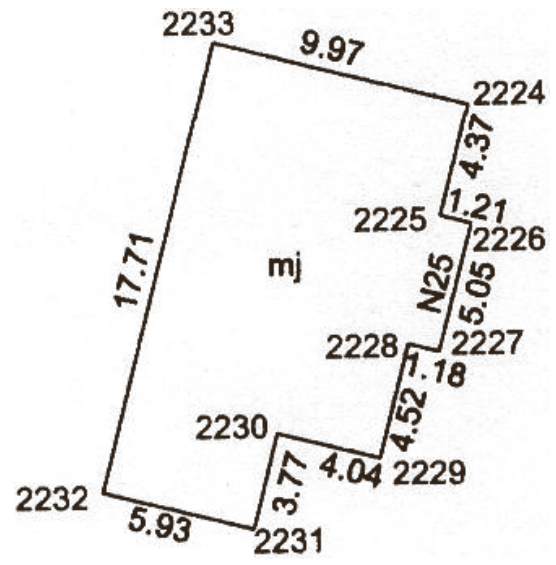

b)

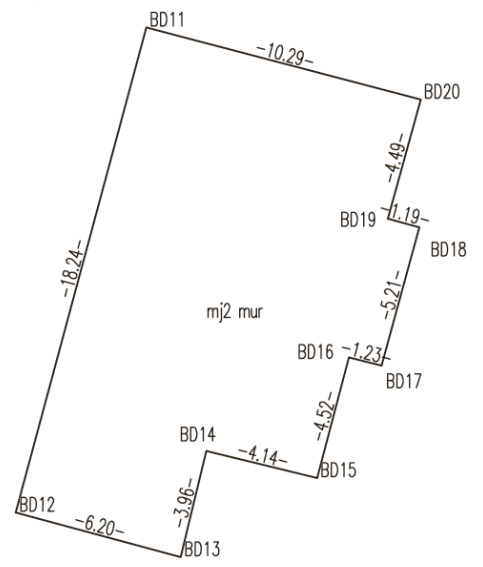

Fig. 3. Field sketch of building located on parcel no. 92 - cadastral measurement: Warsaw's West District Geodetic and Cartographic Resources (a) and author's GNSS control measurement field sketch (b)

\section{Case 2 - building on parcel 33/3}

The analysis of another building examined shows that in some cases a change, that is, an improvement, in the building's geometry occurred between the source data time and the time of control measurement, or that the measurements were taken on the building during (re)construction or before the remedial work was completed. 
Visualization of such differences can be seen in Figure 4. The authors argue that in this case, the comparison of a full data bundle (with all corners measured for analysis) with data obtained from the UAV platform can be done only after a detailed analysis that would provide information on which particular parts of the building were modified. The analysis of field drawings (Fig. 5) shows those elements of the building have been changed.

a)

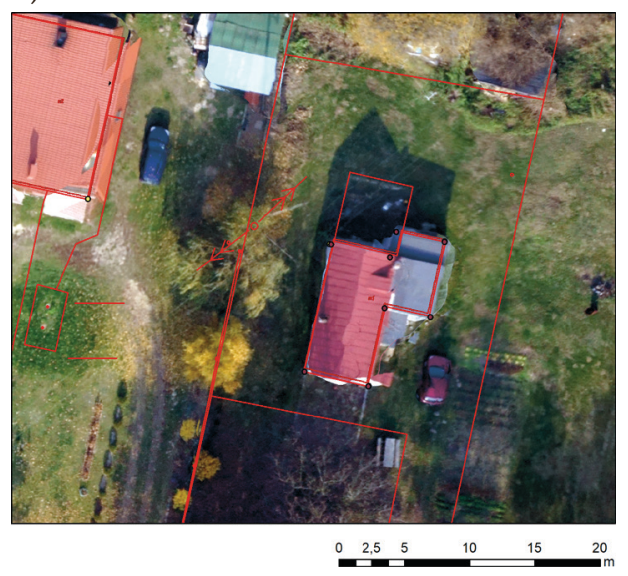

b)

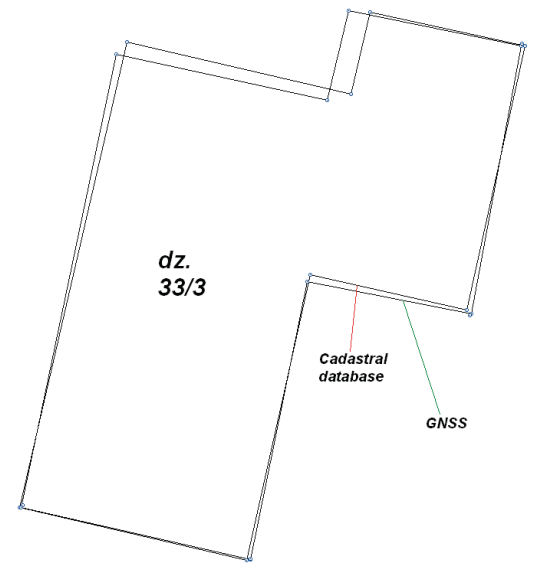

Fig. 4. UAV-based ortomosaic overlaid with cadastral map presenting building on parcel no. 33/3 (a) and outlines of building acquired from cadastral database and UAV data (b)

a)

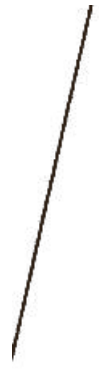

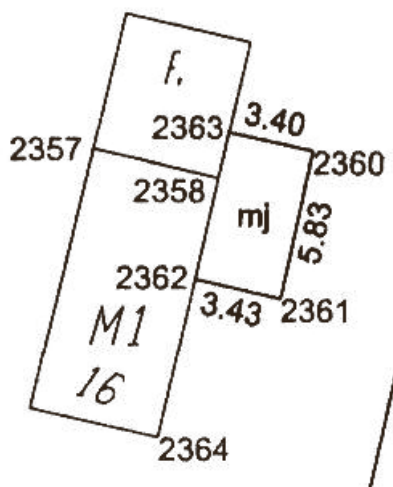

b)

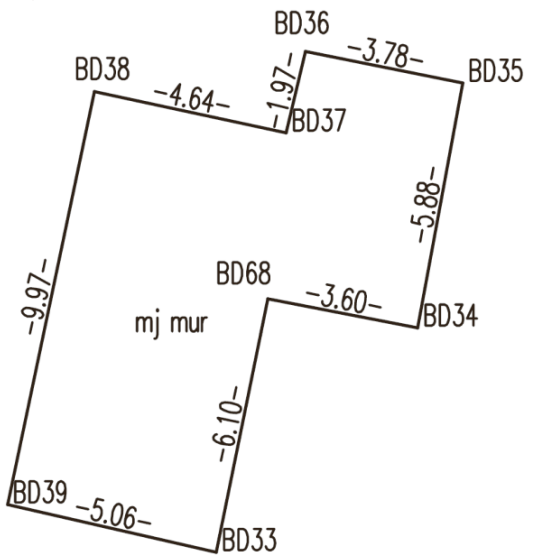

Fig. 5. Field sketch of building located on parcel no. 33/3 - cadastral measurement: Warsaw's West District Geodetic and Cartographic Resources (a) and author's GNSS control measurement field sketch (b) 
Table 2 shows the full compatibility of GNSS control measurement and UAV measurement data. Both measurements presented in different colors, concerned a building with the same condition (geometry, insulation layers, etc.). A comparison of out-of-date cadastral data with the data obtained using measurements based on images collected with the UAV platform would wrongly point to the shortage of this technology. This case shows the inherent necessity to use source documentation analyzes and verification measurements in such a case, as in the case under investigation using GNSS technology.

Table 2. Comparison of coordinates obtained from cadastral database (EGIB) highlighted in green or UAV photogrammetry (highlighted in blue) and from the GNSS control measurement of the authors (black)

\begin{tabular}{|c|c|c|c|c|c|c|c|c||}
\hline \hline \multicolumn{2}{|c|}{ Cadastral database/UAV measurement } & \multicolumn{3}{|c|}{ GNSS measurement } & dX [m] & $\mathrm{d} Y[\mathrm{~m}]$ & $\mathrm{d} p[\mathrm{~m}]$ \\
\hline Point id & $X$ & $Y$ & Point id & $X$ & $Y$ & & & \\
\hline \hline $16 \mathrm{E}$ & 5790297.76 & 7463800.52 & BD38 & 5790297.50 & 7463800.29 & 0.26 & 0.23 & 0.35 \\
\hline 107 & 5790297.53 & 7463800.16 & BD38 & 5790297.50 & 7463800.29 & 0.03 & -0.13 & 0.14 \\
\hline $17 \mathrm{E}$ & 5790296.65 & 7463805.33 & BD37 & 5790296.52 & 7463804.82 & 0.13 & 0.51 & 0.53 \\
\hline $18 \mathrm{E}$ & 5790298.41 & 7463805.74 & BD36 & 5790298.44 & 7463805.28 & -0.03 & 0.46 & 0.46 \\
\hline 106 & 5790298.55 & 7463805.20 & BD36 & 5790298.44 & 7463805.28 & 0.11 & -0.08 & 0.13 \\
\hline $19 \mathrm{E}$ & 5790297.69 & 7463809.06 & BD35 & 5790297.69 & 7463808.99 & 0.00 & 0.07 & 0.07 \\
\hline 105 & 5790297.74 & 7463809.00 & BD35 & 5790297.69 & 7463808.99 & 0.04 & 0.01 & 0.05 \\
\hline $20 \mathrm{E}$ & 5790292.00 & 7463807.81 & BD34 & 5790291.91 & 7463807.92 & 0.09 & -0.11 & 0.14 \\
\hline 104 & 5790291.88 & 7463807.88 & BD34 & 5790291.91 & 7463807.92 & -0.03 & -0.04 & 0.05 \\
\hline $21 \mathrm{E}$ & 5790292.75 & 7463804.46 & BD68 & 5790292.60 & 7463804.39 & 0.15 & 0.07 & 0.17 \\
\hline 15 & 5790286.61 & 7463803.09 & BD33 & 5790286.62 & 7463803.17 & -0.01 & -0.08 & 0.08 \\
\hline 103 & 5790286.65 & 7463803.17 & BD33 & 5790286.62 & 7463803.17 & 0.03 & 0.00 & 0.03 \\
\hline 14 & 5790287.74 & 7463798.21 & BD39 & 5790287.74 & 7463798.24 & 0.00 & -0.03 & 0.03 \\
\hline 102 & 5790287.79 & 7463798.27 & BD39 & 5790287.74 & 7463798.24 & 0.05 & 0.03 & 0.06 \\
\hline
\end{tabular}

\section{Case 3 - building on parcel 9/19}

The next case studied was a building in plot 9/19. Here, the source material was not the data from the modernized cadastral records but from an inventory measurement of the building (field sketch of post inventory survey we can see in Figure 6, 
both with visualization of data). When the measurements were made, the building was already finished and ready for acceptance (building acceptance by the Construction Supervision District Authority) and its geometry did not change until the time of the experiment.

a)

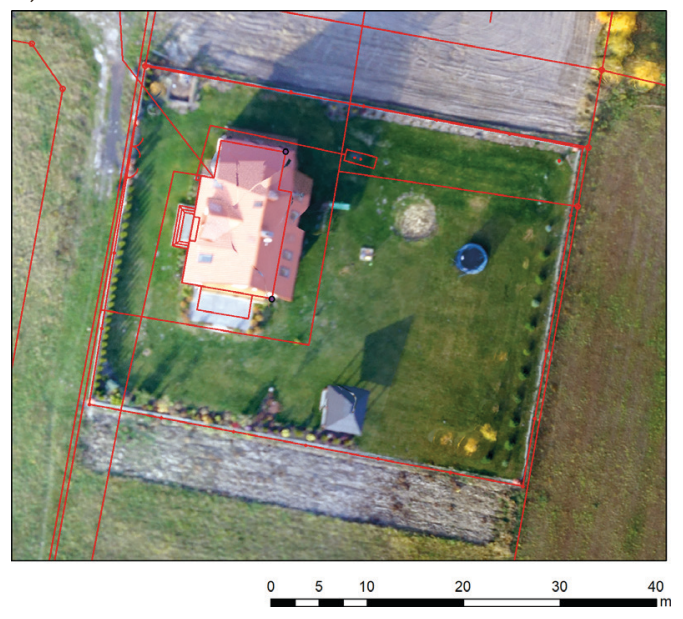

b)

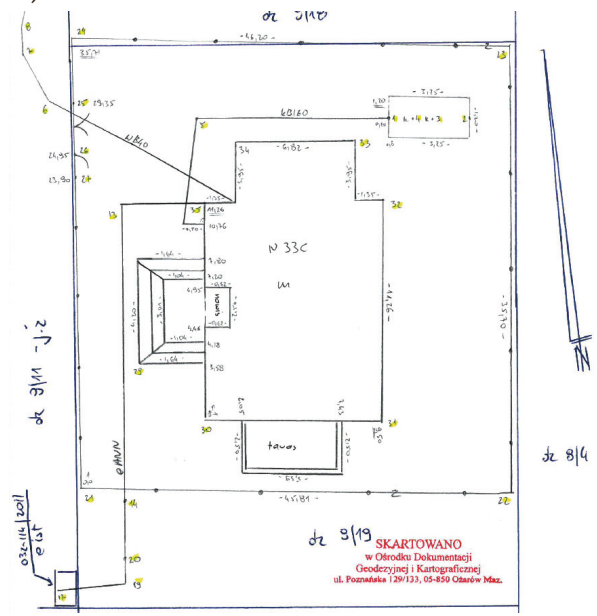

Fig. 6. UAV orthomosaic overlaid with cadastral map presenting building on parcel no. 9/19: authors' field sketch of building - post inventory measurement (a) and Warsaw's West District Geodetic and Cartographic Resources (b)

Table 3 shows the full compatibility of GNSS control measurement and UAVbased data.

Table 3. Comparison of coordinates obtained from UAV photogrammetry and from author's GNSS control measurement

\begin{tabular}{|c|c|c|c|c|c|c|c|c||}
\hline \hline \multicolumn{3}{|c|}{ UAV data } & \multicolumn{3}{c|}{ GNSS measurement } & \multirow{2}{*}{ dX[m] } & $\mathrm{d} Y[\mathrm{~m}]$ & $\mathrm{d} p[\mathrm{~m}]$ \\
\cline { 1 - 9 } Point id & $X$ & $Y$ & Point id & $X$ & $Y$ & & & \\
\hline \hline 50 & 5791288.29 & 7463489.37 & BD255 & 5791288.43 & 7463489.47 & 0.14 & 0.10 & 0.17 \\
\hline 51 & 5791286.75 & 7463498.86 & BD256 & 5791286.72 & 7463498.85 & -0.03 & -0.01 & 0.03 \\
\hline 52 & 5791297.76 & 7463500.76 & BD257 & 5791297.81 & 7463500.89 & 0.05 & 0.13 & 0.13 \\
\hline 70 & 5791302.04 & 7463500.27 & BD258 & 5791302.00 & 7463500.26 & -0.04 & -0.01 & 0.05 \\
\hline 71 & 5791303.26 & 7463493.45 & BD259 & 5791303.21 & 7463493.53 & -0.05 & 0.08 & 0.10 \\
\hline
\end{tabular}




\section{Case 4 - buildings on parcel 36 and 37/2}

The next case study shows the potential of UAV technology to detect gross errors, whereby the permissible degree of accuracy has been exceeded as a result of such errors. The buildings were measured in 1990 as part of the process of updating the base map with direct field methods. The measurement was made from the sides of the polygon traverse with the orthogonal survey method, taking the successive sides of the traverse as the beginning and end of the measurement line. From some points of the polygon traverse, which - it is worth noting - had all sides and angles measured and was related to the national state geodetic network, measurement lines were drawn into the center of the buildings, just as in the described example. The lack of additional observations or verification of the measurement for this element of the traverse put the contractor at a risk of overlooking grave errors and failing to remove them from the final measurements and calculations. Visualization of differences is shown in Figure 7.

a)

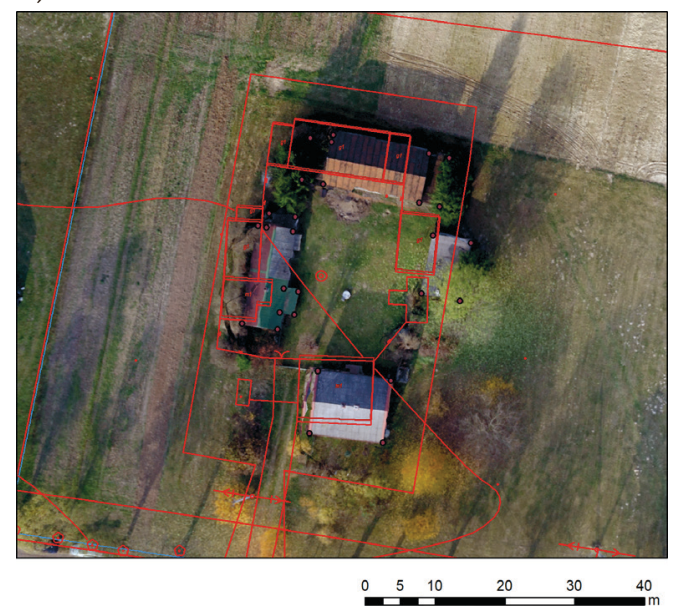

b)

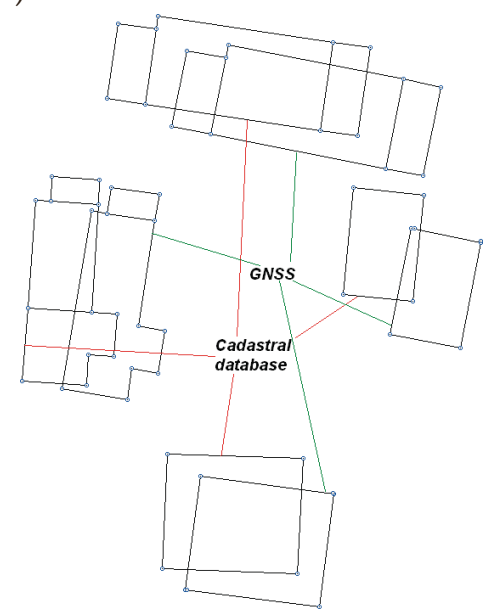

Fig. 7. UAV orthomosaic overlaid with cadastral map presenting errors maintained after EGIB modernization (a) and comparison of building outlines of acquired from cadastral database and GNSS data (b)

In the case described here, the UAV data alone reveals the presence of huge errors. To provide a final confirmation of this fact, the authors performed a transformation of the source measurement coordinates from the then valid Reference System Warszawa 75 into the current State Reference System PUWG 2000, which is currently in force for 9 building corners measured in the archival work directly from the measurement line using the orthogonal method. The obtained differences between the source material and the control GNSS measurement in the location of points marking the building corners ranged from 2.4 to $5.8 \mathrm{~m}$, which confirmed the presence of a significant error in the archival work. The visualization of the building 
outlines generated from the UAV flight results and from archival data and also from GNSS control measurement (Figs. 7,8) gives rise to the assertion that the error was most probably made in measuring the angle between the sides of the traverse and the measurement line (there is a noticeable rotation of terrain, with the distances between buildings unchanged). This error was not noticed during modernization process and UAV data clearly present this problem.

a)

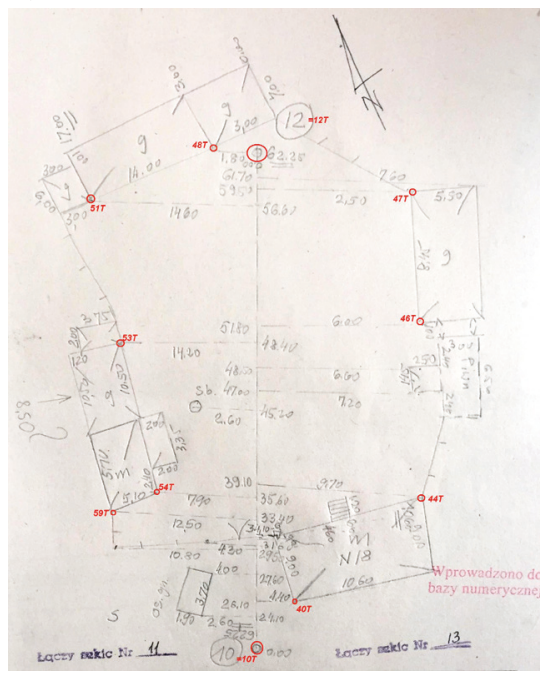

b)
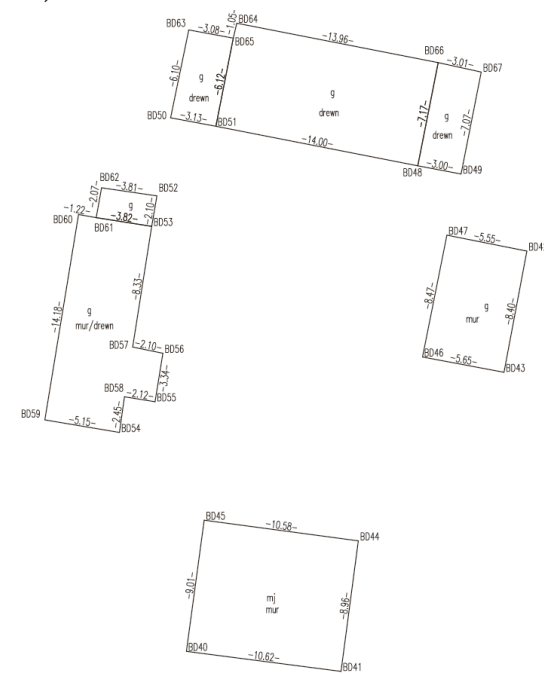

Fig. 8. Field sketch of building - base map updating measurement: Warsaw's West District Geodetic and Cartographic Resources (a) and author's GNSS control measurement field sketch (b)

Next, in order to learn the potential of the UAV technology, data from the UAV was compared with data from the GNSS control measurement, and the obtained differences were not greater than $15 \mathrm{~cm}$ (results are shown in Table 4).

Table 4. Comparison of coordinates obtained from UAV photogrammetry and from author's GNSS control measurement

\begin{tabular}{||c|c|c|c|c|c|c|c|c||}
\hline \multicolumn{3}{|c|}{ UAV data } & \multicolumn{3}{c|}{ GNSS measurement } & & & \\
\cline { 1 - 8 } Point id & $X$ & $Y$ & Point id & $X$ & $Y$ & $\mathrm{~d}[\mathrm{~m}]$ & $\mathrm{d} Y[\mathrm{~m}]$ & $\mathrm{d} p[\mathrm{~m}]$ \\
\hline \hline 125 & 5790325.01 & 7463574.66 & BD45 & 5790325.05 & 7463574.67 & -0.04 & -0.01 & 0.04 \\
\hline 124 & 5790316.10 & 7463573.57 & BD40 & 5790316.12 & 7463573.46 & -0.02 & 0.11 & 0.11 \\
\hline 209 & 5790323.71 & 7463585.04 & BD44 & 5790323.64 & 7463585.16 & 0.07 & -0.13 & 0.14 \\
\hline 208 & 5790314.79 & 7463583.99 & BD41 & 5790314.76 & 7463583.99 & 0.03 & 0.00 & 0.03 \\
\hline
\end{tabular}




\subsection{Results of Analysis and Comparison of Data on Test Object}

The overall data from UAV and GNSS measurements showed that both methods are as precise as direct field measurements when used to obtain geometric data for buildings. The authors compared the coordinates after rejecting cases similar to those described above, where either massive errors were made or the buildings measured were changed in the period between the source data collection and the time of the experiment. The results of the analysis and comparisons are as follows: for 78 points out of the total 92 points (that is $85 \%$ ), the differences obtained were between 0.00 and $0.16 \mathrm{~m}$; for 9 points out of the $92(10 \%)$, the differences obtained ranged from 0.17 to $0.25 \mathrm{~m}$; for the remaining 5 points out of the $92(5 \%)$, the obtained differences were not greater than $0.25 \mathrm{~m}$, and for 3 of those 5 points, the difference did not exceed $0.30 \mathrm{~m}$. The average error was $m_{X}=0.07 \mathrm{~m}, m_{Y}=0.09 \mathrm{~m}$. No systematic errors were found.
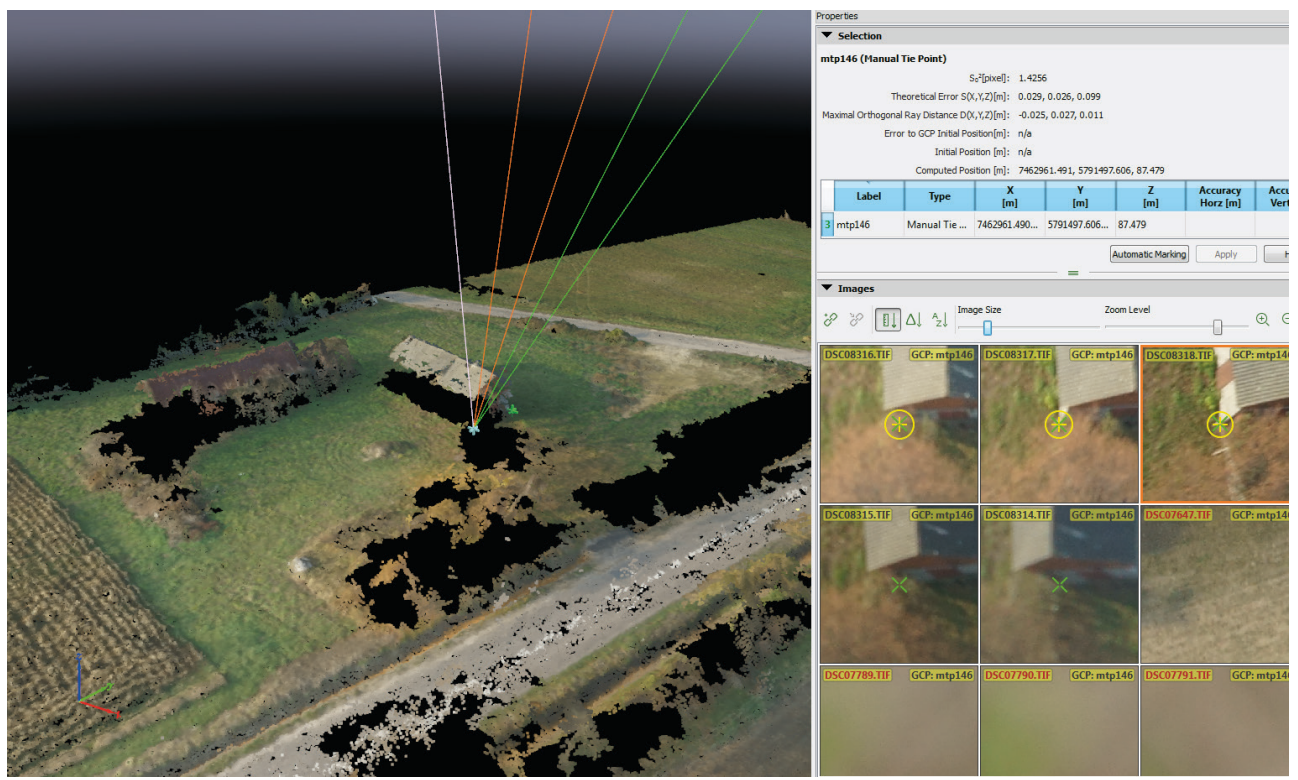

Fig. 9. Multiple space intersections on a 3D model (Pix4D software)

Figures 9 and 10 give a graphical representation of the method for making multiple space intersections on a 3D model. They show 3D point cloud and image rays on the left-hand side and several high-resolution UAV images allowing for measurements or performing that such measurement is impossible due to occlusions). These figures show the contrast between a poor number of rays within a photogrammetric measurement (Fig. 9) and a high, redundant number of observations sufficient to guarantee the appropriate degree of accuracy (Fig. 10). Although corners are visible 
in many images, the possible identification is not always sufficient to ensure that the data is correct. Corners are sometimes overshadowed or obscured by trees or bushes (Fig. 9). For example, the corner was visible in an average of 6.5 images out of the intersections made for 164 corners. The extreme values were 2 and 20. Even after discarding these extreme values, the average would remain close to 6.5. On the outlines of the photogrammetric work, a visually poorer image of the 3D model was obtained.
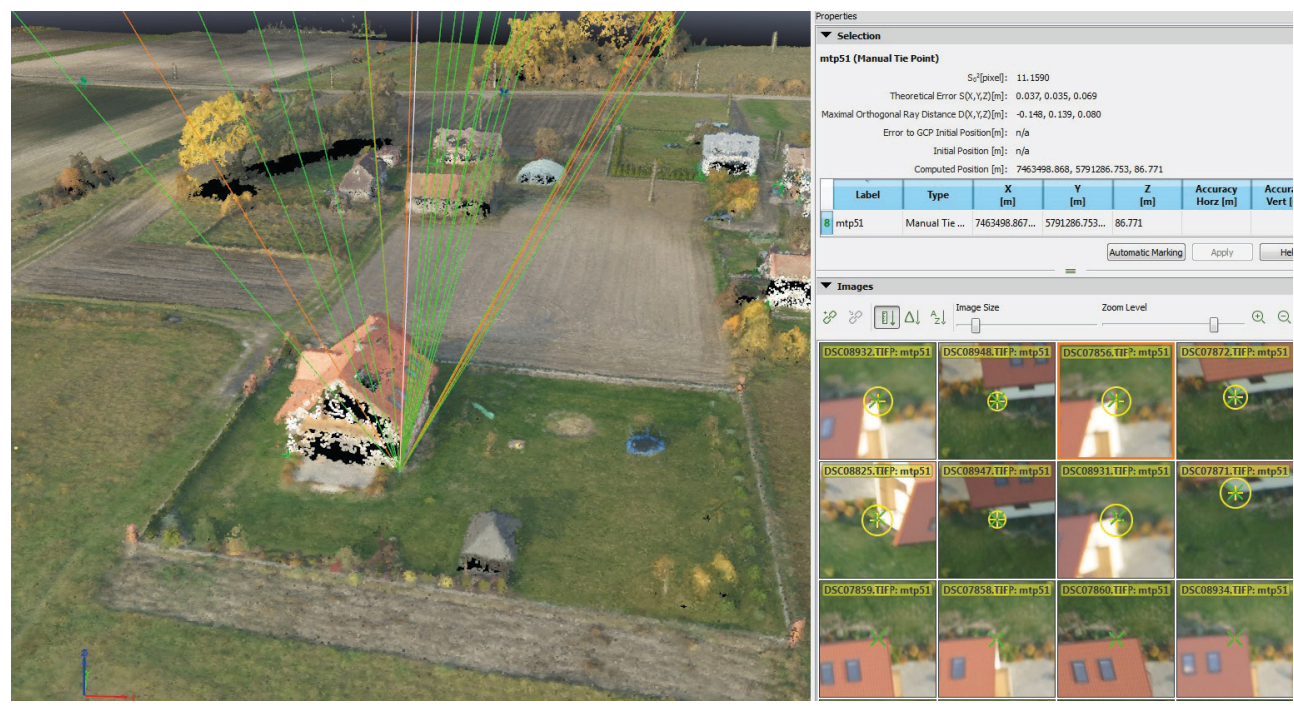

Fig. 10. Multiple space intersections on a 3D model (Pix4D software)

\section{Discussion and Conclussion}

The work of Kurczyński et al. [8] demonstrated that UAVs have great potential to create high-resolution and highly accurate orthophoto and photogrammetric measurements. The conducted experiment confirmed that data from unmanned $\mathrm{UAV}$ platforms can be a viable alternative to traditional field measurements, as well as those performed with the use of GNSS satellite methods. UAVs offer a high measurement potential, with a degree of accuracy close to large format photogrammetry; they also meet the requirements for measuring cadastral data to update field details particularly for buildings.

The analysis of special cases and the work on the 3D model obtained from the UAV data shows that data from UAVs must be updated and checked against field measurements, as many objects cannot be measured photogrammetrically. Currently, legal considerations allow using UAV measurements to be applied to update data on the boundaries of cadastral parcels, but after setting the previous 
parcels' boundaries in a field by their owners. Data obtained in this way may also be useful in verifying the process of updating. Legal provisions, including the regulation [4], do not specify the techniques for obtaining data on field objects, but only regard the fulfillment of relevant precision criteria as a priority. Therefore, in the scope of obtaining data about buildings, the legal regulations do not restrict the surveyor.

A major limit to this type of work is the area from which data can be obtained, because only a few square kilometers can be covered in one day. In the case of forested land, traditional methods of survey are recommended and UAV surveys should be supported by other methods such as GNSS.

\section{Author Contribution}

M.K.: conceptualization, methodology, validation, analysis, resources, original draft preparation. K.B.: conceptualization, methodology, validation, supervision, photogrammetric surveys, original draft preparation. R.Ł.: field GNSS measurement, original draft preparation

\section{Acknowledgements}

The authors would like to thank the MSP company for its cooperation with photogrammetric works, providing UAV images used in the presented experiments. The authors also thank Mr Dariusz Pręgowski - the Warsaw-Western district county surveyor for his assistance in obtaining reference data.

\section{References}

[1] Rozporzadzenie Ministra Rozwoju Regionalnego i Budownictwa z dnia 29 marca 2001 r. w sprawie ewidencji gruntów i budynków. Tekst jednolity Dz.U. 2019 poz. 393 [Regulation of the Minister of Regional Development and Construction of 29 March 2001 on cadastre].

[2] Łuczyński R.: Geodetic and legal aspects of real property in the information area. [in:] Źróbek R. (ed.), Management of real estate resources, Croatian Information Technology Society - GIS Forum, Zagreb, Croatia, University of Warmia and Mazury in Olsztyn, Poland, University of Silesia, Poland, 2013, pp. 76-84.

[3] Rozporzadzenie Ministrów Spraw Wewnętrznych i Administracji oraz Rolnictwa i Gospodarki Żywnościowej z dnia 14 kwietnia 1999 r. w sprawie rozgraniczania nieruchomości. Dz.U. 1999 nr 45, poz. 453 [Regulation of the Ministers of the Interior and Administration as well as Agriculture and Food Economy of April 14, 1999 on the delimitation of real estate].

[4] Rozporzadzenie Ministra Rozwoju, Pracy i Technologii z dnia 27 lipca 2021 r. w sprawie ewidencji gruntów i budynków. Dz.U. 2021 poz. 1390 [Regulation of the Minister of Development, Labor and Technology of 27 July 2021 on the cadastre]. 
[5] Rozporzadzenie Ministra Rozwoju z dnia 18 sierpnia 2020 r. w sprawie standardów technicznych wykonywania geodezyjnych pomiarów sytuacyjnych $i$ wysokościowych oraz opracowywania i przekazywania wyników tych pomiarów do państwowego zasobu geodezyjnego i kartograficznego. Dz.U. 2020 poz. 1429 [Regulation of the Minister of Development of 18 August 2020 on technical standards for the performance of geodetic situational and height measurements as well as the development and transfer of the results of these measurements to the state geodetic and cartographic resource].

[6] Cienciała A., Sobolewska-Mikulska K., Sobura S.: Credibility of the cadastral data on land use and the methodology for their verification and update. Land Use Policy, vol. 102, 2021, 105204. https://doi.org/10.1016/j.landusepol.2020.105204.

[7] Yaprak S., Yildirim O., Susam T.: New approach for agricultural research and monitoring of land slide: using of UAV system. Journal of Environmental Protection and Ecology, vol. 19, no. 1, 2018, pp. 246-256.

[8] Kurczyński Z., Bakuła K., Karabin M., Kowalczyka M., Markiewicz J.S., Ostrowski W., Podlasiak P., Zawieska D.: The possibility of using images obtained from the UAS in cadastral works. The International Archives of the Photogrammetry, Remote Sensing and Spatial Information Sciences, vol. XLI-B1, 2016, pp. 909-915. https://doi.org/10.5194/isprsarchives-XLI-B1-909-2016.

[9] Crommelinck S., Bennett R., Gerke M., Yang M.Y., Vosselman G.: Contour Detection for UAV-Based Cadastral Mapping. Remote Sensing, vol. 9(2), 2017, 171. https://doi.org/10.3390/rs9020171.

[10] Puniach E., Bieda A., Ćwiąkała P., Kwartnik-Pruc A., Parzych P.: Use of unmanned aerial vehicles (UAVs) for updating farmland cadastral data in areas subject to landslides. ISPRS International Journal of Geo-Information, vol. 7(8), 2018, 331. https://doi.org/10.3390/ijgi7080331.

[11] Ogryzek M., Klimach A., Niekurzak D., Pietkiewicz M.: Using cartographic documents to provide geoinformation on the rights to real estate - taking Poland as an example. ISPRS International Journal of Geo-Information, vol. 8(12), 2019, 530. https://doi.org/10.3390/ijgi8120530.

[12] Szeremeta K., Lubański M.: Praktyczne zastosowania BSP w opracowaniu założeń do projektów scaleń gruntów. Przegląd Geodezyjny, R. 92, nr 9, 2020, pp. 14-18. https://doi.org/10.15199/50.2020.9.1.

[13] Pyka K., Wiącek P., Guzik M.: Surveying with photogrammetric unmanned aerial vehicles. Archives of Photogrammetry. Cartography and Remote Sensing, vol. 32, 2020, pp. 79-102.

[14] Šafář. V., Potůčková M., Karas J., Tlustý J., Štefanová E., Jančovič M., Cígler Žofková D.: The Use of UAV in Cadastral Mapping of the Czech Republic. ISPRS International Journal of Geo-Information, vol. 10(6), 2021, 380. https://doi.org/ 10.3390/ijgi10060380. 
[15] Fetai B., Oštir K., Kosmatin Fras M., Lisec A.: Extraction of visible boundaries for cadastral mapping based on UAV imagery. Remote Sensing, vol. 11(13), 2019, 1510. https://doi.org/10.3390/rs11131510.

[16] Stöcker C., Koeva M.N., Nkerabigwi P., Zevenbergen J.A.: UAV Technology: Opportunities to support the updating process of the Rwandan cadastre. [in:] FIG Working Week 2020. https://www.fig.net/resources/proceedings/fig_proceedings/fig2020/papers/ts07h/TS07H_stocker_koeva_et_al_10290.pdf [access: 30.06.2021].

[17] Karataş K., Altinişik N.S.: The Effect of UAV Usage on Detail Points in Cadastre Update Studies: Çorum-Karaköy Case Study. International Journal of Environment and Geoinformatics, vol. 7(2), 2020, pp. 140-146. https://doi.org/ 10.30897/ijegeo.646155.

[18] Koeva M., Muneza M., Gevaert C., Gerke M., Nex F.: Using UAVs for map creation and updating. A case study in Rwanda. Survey Review, vol. 50(361), 2018, pp. 312-325. https://doi.org/10.1080/00396265.2016.1268756.

[19] Stöcker C., Bennett R., Nex F., Gerke M., Zevenbergen J.: Review of the Current State of UAV Regulations. Remote Sensing, vol. 9(5), 2017, 459. https://doi.org/ 10.3390/rs9050459.

[20] Vacca G., Dessì A., Sacco A.: The Use of Nadir and Oblique UAV Images for Building Knowledge. ISPRS International Journal of Geo-Information, vol. 6(12), 2017, 393. https://doi.org/10.3390/ijgi6120393.

[21] Kędzierski M.: Analiza możliwości wykorzystania zobrazowań satelitarnych $i$ danych obrazowych z bezzałogowych statków powietrznych we wspótczesnych opracowaniach fotogrametrycznych [Analysis of possibility of using satellite and UAV imagery in modern photogrammetry]. Przegląd Geodezyjny, R. 88, nr 12, 2016, pp. 5-13. https://doi.org/10.15199/50.2016.12.1.

[22] Kurczyński Z., Bakuła K.: Ocena możliwości współczesnej fotogrametrii z pracach $z$ zakresu ewidencji gruntów i budynków [Possibility assessment of modern photogrammetry for works related to land and building register]. Przegląd Geodezyjny, R. 88, nr 7, 2016, pp. 2-10. https://doi.org/10.15199/50.2016.7.1.

[23] Stępień G., Sanecki J., Klewski A., Beczkowski K.: Wyznaczanie granic użytków rolnych z wykorzystaniem bezzałogowych systemów latających [Determination of agricultural land borders using unmanned aerial systems]. Infrastruktura i Ekologia Terenów Wiejskich, nr III/2, 2016, pp. 1011-1024. https://doi. org/10.14597/infraeco.2016.3.2.074. 